$n^{n}$

SC-DR-69-491

August 1969

967

EXPER IMENTALLY DETERMINED DYNAMIC SHEAR STRENGTH FOR SELECTED MATERIALS (GUN TEST FACILITY)

J. H. Biffle, 1542

R. E. Berry, 9512

AEROSPACE NUCLEAR SAFETY DEPARTMENT 9510 


\section{DISCLAIMER}

This report was prepared as an account of work sponsored by an agency of the United States Government. Neither the United States Government nor any agency Thereof, nor any of their employees, makes any warranty, express or implied, or assumes any legal liability or responsibility for the accuracy, completeness, or usefulness of any information, apparatus, product, or process disclosed, or represents that its use would not infringe privately owned rights. Reference herein to any specific commercial product, process, or service by trade name, trademark, manufacturer, or otherwise does not necessarily constitute or imply its endorsement, recommendation, or favoring by the United States Government or any agency thereof. The views and opinions of authors expressed herein do not necessarily state or reflect those of the United States Government or any agency thereof. 


\section{DISCLAIMER}

Portions of this document may be illegible in electronic image products. Images are produced from the best available original document. 
Issued by Sandia Corporation,

a prime contractor to the

United States Atomic Energy Commission

\section{LE G A L N O T I C E}

This report was prepared as an account of Government sponsored work. Neither the United States, nor the Commission, nor any person acting on behalf of the Commission.

A. Makes any warranty or representation, expressed or implied, with respect to the accuracy, completeness, or usefulness of the information contained in this report, or that the use of any information, apparatus, method, or process disclosed in this report may not infringe privately owned rights, or

B. Assumes any liabilities $w_{1}$ th respect to the use of, or for damages resulting from the use of any information, apparatus, method, or process disclosed in this report.

As used in the above, "person acting on behalf of the Commission" includes any employee or contractor of the Commission, or employee of such contractor, to the extent that such employee or contractor of the Commission, or employee of such contractor prepares, disseminates, or provides access to, any information pursuant to his employment or contract with the Commission, or his employment with such contractor.

Printed in the United States of America

Avallable from

Clearinghouse for Federal Scientufic and Technical Information

National Bureau of Standards, U. S. Department of Commerce

Springfield, Virginia 22151

Price: Printed Copy $\$ 3.00$; Microfiche $\$ 0.65$ 


$$
\text { SC-DR-69-491 }
$$

EXPERIMENTALLY DETERMINED DYNAMIC SHEAR STRENGTH FOR SELECTED MATERIALS (GUN TEST FACILITY)

J. H. Biffle, 1542

R. E. Berry, 9512

Sandia Laboratories, Albuquerque

August 1969

Approved by:
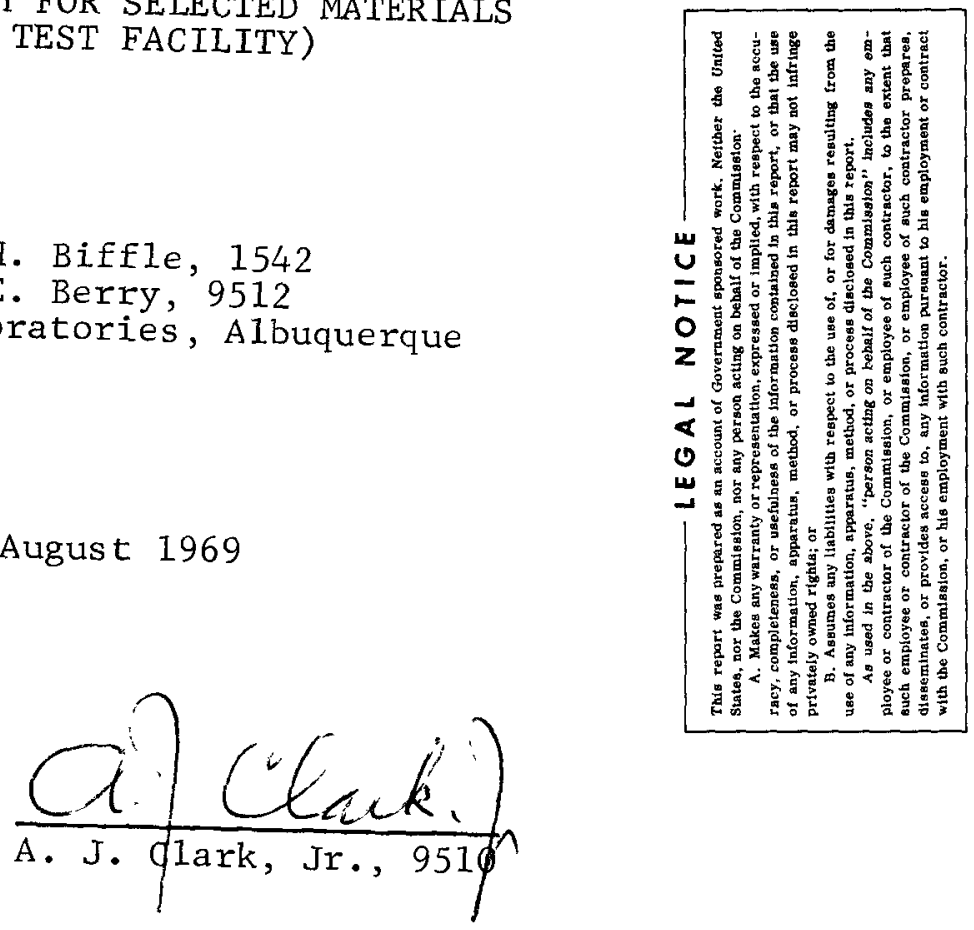

\section{ABSTRACT}

Cylindrical projectiles were impacted on selected materials to permit the calculation of the materials dynamic shear strengths. The materials were beryllium, Haynes -25 alloy, and titanium (6Al-4V) lunar module fuel cask and fuel construction for the SNAP-27 graphite

The cutoff date for information in this report is October 1968. 


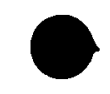

1

BLANK 
The materials of construction for the SNAP-27 graphite lunar module fuel cask and fuel capsule assembly were subjected to impacts of cylindrical projectiles. These tests were performed on beryllium, Haynes -25 alloy, and titanium $(6 \mathrm{~A} 1-4 \mathrm{~V})$ alloy at various projectile velocities. The velocity was increased until perforation was accomplished. The tests were performed at the operational temperature expected during the launch pad phase of the Saturn $V$ launch vehicle.

Beryllium exhibited brittle fracture at $900^{\circ} \mathrm{F}$, while the other materials exhibited shear plug failure. Haynes -25 alloy at $1200^{\circ} \mathrm{F}$ had a calculated dynamic shear strength of $971,000 \mathrm{psi}$, and titanium alloy at $1100^{\circ} \mathrm{F}$ had a calculated dynamic shear strength of 266,000 psi. 
TABLE OF CONTENTS

Page

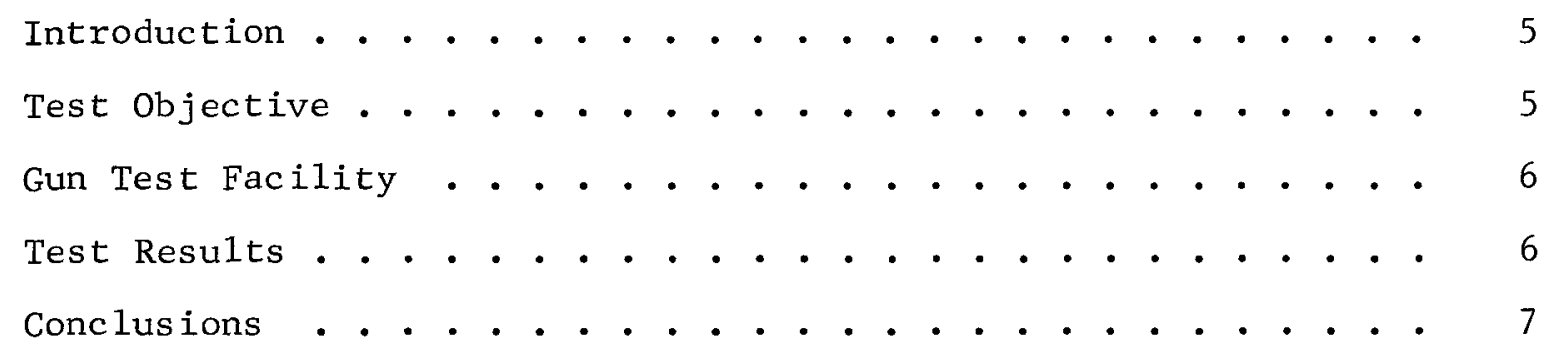




\title{
EXPERIMENTALLY DETERMINED DYNAMIC SHEAR STRENGTH FOR SELECTED MATERIALS \\ (GUN TEST FACILITY)
}

\author{
Introduction
}

A test series was designed to establish the dynamic shear strengths of the materials used in the SNAP-27 secondary thermal shield (STS) and the fuel capsule assembly (FCA). The materials tested were beryllium, Haynes -25 alloy, and titanium $(6 \mathrm{~A} 1-4 \mathrm{~V})$ a11oy.

The dynamic shear strength, when determined for the test conditions used, is a quantity which is assumed to be constant for the given material and is used in the analytical model of Recht and Ipson in Reference 1. The term is present in the strain energy portion of the total energy expression of the deformation process. The value is obtained from an experimentally determined minimum perforation velocity which is described by Eq. (7) of Reference 1.

The dynamic shear strength is needed to permit calculation of the penetration resistance of the tested materials during the impact of debris generated during an explosive abort of the S-IVB stage of the Saturn V launch vehicle.

There are techniques for calculating the penetration of simple shapes by cylindrical projectiles, but the dynamic shear strengths of the materials of interest are not available and were required to complete the calculations for the penetration resistance of the SNAP-27 GLFC.

Test Objectives

Explosively propelled aluminum projectiles were impacted against plates of beryllium, Haynes -25 alloy, and titanium a11oy to determine the dynamic shear strengths of these materials. The plates were impacted at velocities sufficient to cause perforation. The object of the test was to determine the dynamic shear strength property of the material so as to be able to use this property in the analytical model of Recht and Ipson.1 A11 the tests were conducted with the target materials at approximately the operating temperature expected during the on-pad operational phase of the SNAP-27 graphite lunar module fuel cask (GLFC).

The plates were impacted at increasing velocities until perforation was accomplished; then the velocity was decreased in smaller increments until the projectile did not penetrate. This range of velocity for perforation or nonperforation was used to calculate the dynamic shear strength of each material for the test temperature. 
The gun test facility consists of a 0.50 -caliber smooth bore rifle barrel attached to a modified 0.50 -caliber gun receiver. The receiver was modified to allow electric pulse firing of the gun.

The aluminum cylindrical projectile was loaded in a standard 0.50 -caliber cartridge case. The powder charge was varied to acquire the desired velocity of the projectile. The original test setup is shown in Figure 1 . However, the rigid mounting was considered detrimental to the testing and was modified to allow the plate to be suspended from wires and backed up by three fingers to prevent swinging upon projectile impact (Figure 2). As noted in Figure 1 the plates were radiantly heated prior to projectile impact. The plates were heated to the nominal operating temperatures expected on the launch pad prior to actual launch vehicle lift off.

\section{Test Results}

The materials tested were beryllium, Haynes -25 alloy, and titanium $(6 \mathrm{~A} 1-4 \mathrm{~V})$ alloy. These materials were 0.375 inch, 0.040 inch, and 0.125 inch thick, respectively. They were heated to approximately $900^{\circ}, 1200^{\circ}$, and $1100^{\circ} \mathrm{F}$, respectively, prior to projectile impact. Each plate was impacted at increasing velocity until either perforation was experienced or fracture occurred.

The two beryllium plates exhibited a brittle fracture of the entire plate (Figures 3 through 8 ), while the titanium and Haynes -25 exhibited a shear plug type of failure (Figures 9 through 12). The entire test series is summarized in Table $I$.

\section{Titanium}

The titanium plate was 0.125 inch thick and was mounted so that it could not swing away from the projectile but could rebound forward after projectile impact. The titanium used in the test was annealed plate and contained 6 percent aluminum and 4 percent vanadium. The projectile was a 0.50 -inch diameter by 2.0 -inch long aluminum rod. A minimum perforation velocity of $830 \mathrm{ft} / \mathrm{sec}$ at $1100^{\circ} \mathrm{F}$ was found. Using these results in the analytical model resulted in a calculated dynamic shear strength of 266,000 psi. The shear plug produced by the projectile was approximately 0.50 inch in diameter.

\section{Haynes-25 Alloy}

The Haynes -25 alloy plate was 0.040 inch thick and was mounted so that it could not swing away from the projectile but could rebound forward after projectile impact. The projectile was a 0.50-inch diameter by 1.0 -inch long aluminum rod. A minimum perforation velocity of $750 \mathrm{ft} / \mathrm{sec}$ at $1200^{\circ} \mathrm{F}$ was found. A dynamic shear strength of 971,000 psi was calculated for the Haynes -25 alloy. The shear plug produced by the projectile was approximately the same diameter as the projectile. 


\section{Beryllium}

The beryllium tests resulted in fracture of the entire plate and therefore were not applicable to the analys is since a shear plug must be formed. A 0.50 -inch diameter by 2 -inch long aluminum rod did not produce a hole in the 0.375 -inch beryllium plate at $700 \mathrm{ft} / \mathrm{sec}$. The first test of the beryllium plate resulted in the plate spalling and radially cracking from the impact point; the velocity was $670 \mathrm{ft} / \mathrm{sec}$. The second test of the beryllium plate resulted in the plate spalling and shattering into six pie-shaped pieces. The velocity was $700 \mathrm{ft} / \mathrm{sec}$. The target plate was an end slice of a 12-inch diameter cylinder of hot pressed block. The test temperature was $900^{\circ} \mathrm{F}$.

\section{Conclusions}

These test demonstrated that beryllium at $900^{\circ} \mathrm{F}$ and under impact conditions exhibits a brittle fracture type failure; Haynes -25 alloy at $1200^{\circ} \mathrm{F}$ and titanium $(6 \mathrm{~A} 1-4 \mathrm{~V})$ alloy at $1100^{\circ} \mathrm{F}$ under impact conditions exhibit a shear plug type failure. The two materials exhibiting shear plug type failure have calculated dynamic shear strengths of 971,000 and 266,000 psi, respectively. 
TABLE I

Results of Test Series

\begin{tabular}{|c|c|c|c|c|}
\hline Materia 1 & $\begin{array}{l}\text { Impact } \\
\text { Velocity } \\
\text { (ft/sec) }\end{array}$ & $\begin{array}{c}\text { Temperature } \\
\text { at Impact } \\
\left({ }^{\circ} \mathrm{F}\right)\end{array}$ & Penetration & $\begin{array}{c}\text { Projectile } \\
\text { (Aluminum 2024-T6) } \\
\text { Size } \\
\text { (in.) }\end{array}$ \\
\hline $\begin{array}{l}\text { Titanium } \\
(6 \mathrm{~A} 1-4 \mathrm{~V})\end{array}$ & $\begin{array}{l}840 \\
450 \\
615 \\
913 \\
825\end{array}$ & $\begin{array}{l}1100 \\
1100 \\
1100 \\
1100 \\
1100\end{array}$ & $\begin{array}{l}\text { Yes } \\
\text { No } \\
\text { No } \\
\text { Yes } \\
\text { No } 6\end{array}$ & $\begin{array}{l}0.5 \text { dia. } \times 2 \\
0.5 \text { dia. } \times 2 \\
0.5 \text { dia. } 22 \\
0.5 \text { dia. } x 2 \\
0.5 \text { dia. } \times 2\end{array}$ \\
\hline Haynes -25 A11oy 2 & $\begin{array}{l}347 \\
406 \\
490 \\
760 \\
720\end{array}$ & $\begin{array}{l}1200 \\
1200 \\
1200 \\
1200 \\
1200\end{array}$ & $\begin{array}{l}\text { No } \\
\text { No } \\
\text { No } \\
\text { Yes } \\
\text { No }\end{array}$ & $\begin{array}{l}0.5 \text { dia. } \times 1 \\
0.5 \text { dia. } \times 1 \\
0.5 \text { dia. } \times 1 \\
0.5 \text { dia. } \times 1 \\
0.5 \text { dia. } \times 1\end{array}$ \\
\hline $\begin{array}{l}\text { Beryllium }{ }^{3,4} \\
\text { Beryllium }^{5}\end{array}$ & $\begin{array}{l}670 \\
700\end{array}$ & $\begin{array}{l}920 \\
900\end{array}$ & $\begin{array}{l}\text { Brittle fracture } \\
\text { occurred and there- } \\
\text { fore analyses cannot } \\
\text { be performed. A } \\
\text { shear plug must be } \\
\text { formed. }\end{array}$ & $\begin{array}{l}0.5 \text { dia. } \times 2 \\
0.5 \text { dia. } \times 2\end{array}$ \\
\hline \multicolumn{5}{|c|}{$\begin{array}{l}1 \text { - Titanium plates were } 0.125 \text {-inch thick. } \\
2 \text { - Haynes }-25 \text { alloy plates were } 0.40 \text { inch thick. } \\
3 \text { - Beryllium plates were } 0.375 \text { inch thick. } \\
4 \text { - First beryllium plate was rigidly supported. } \\
5 \text { - Second beryllium plate had three-finger support, as did all titanium and } \\
\text { Haynes }-25 \text { plates. } \\
6 \text { - Cracked dent. }\end{array}$} \\
\hline
\end{tabular}




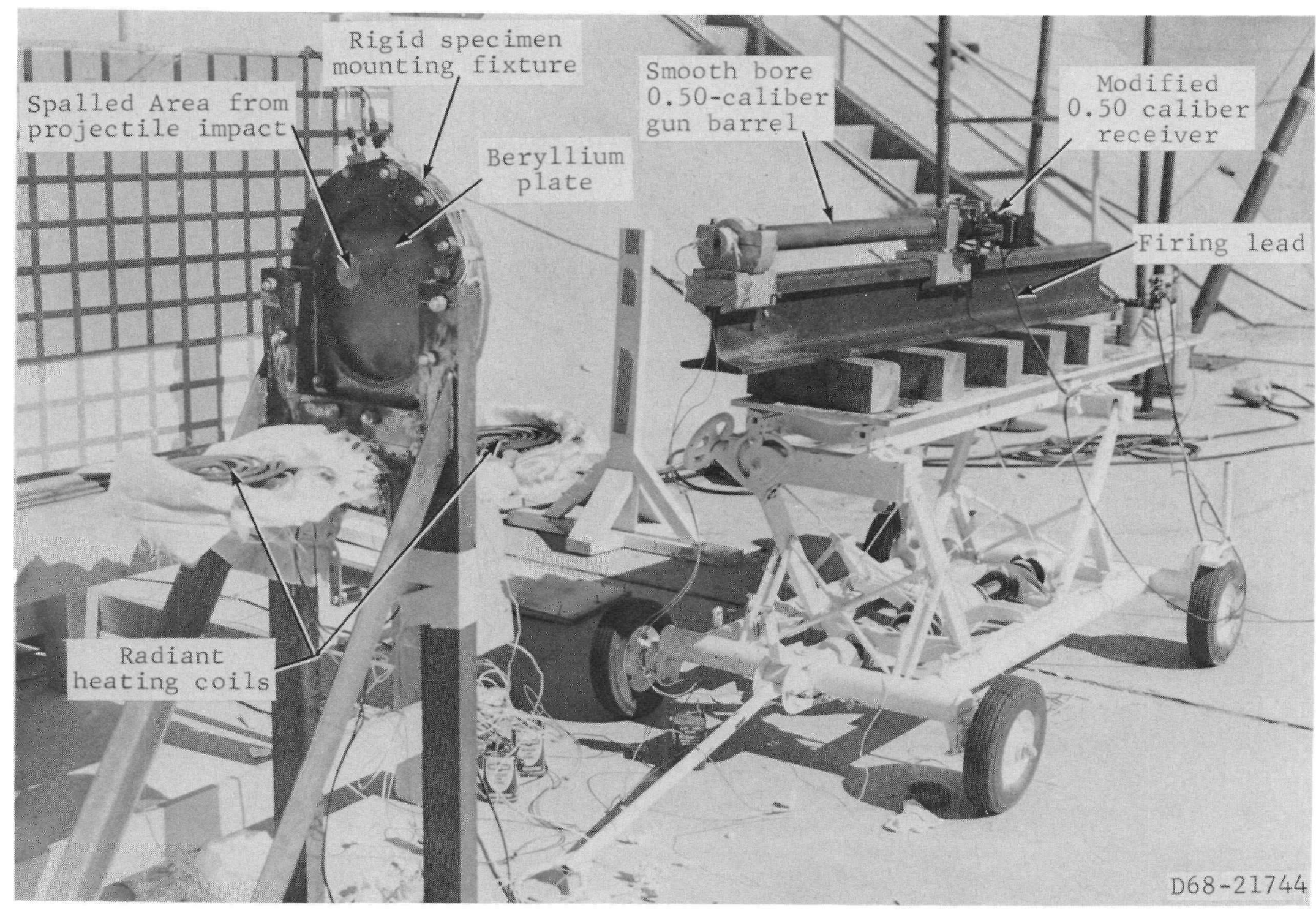




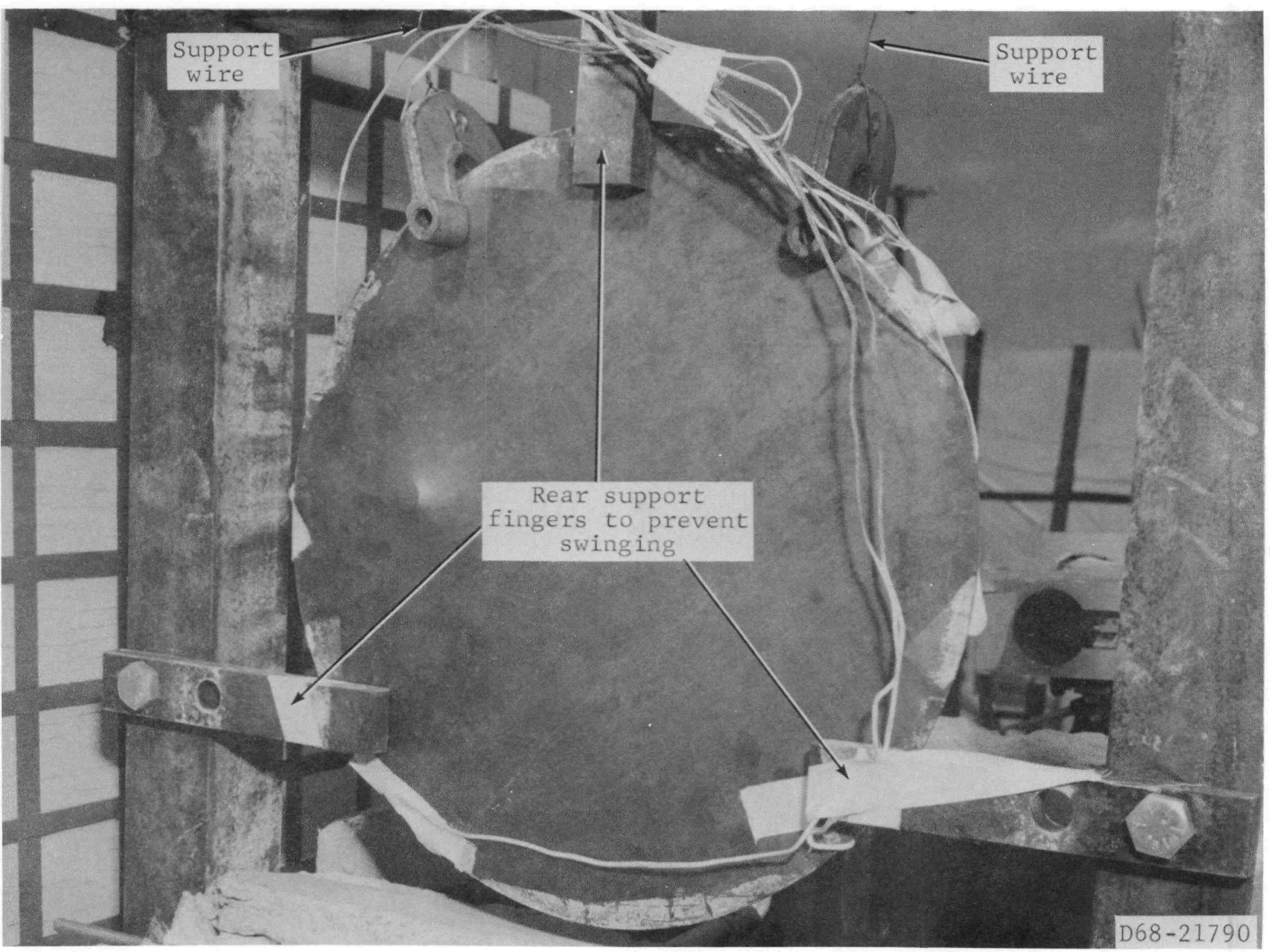

Figure 2. Final test setup 


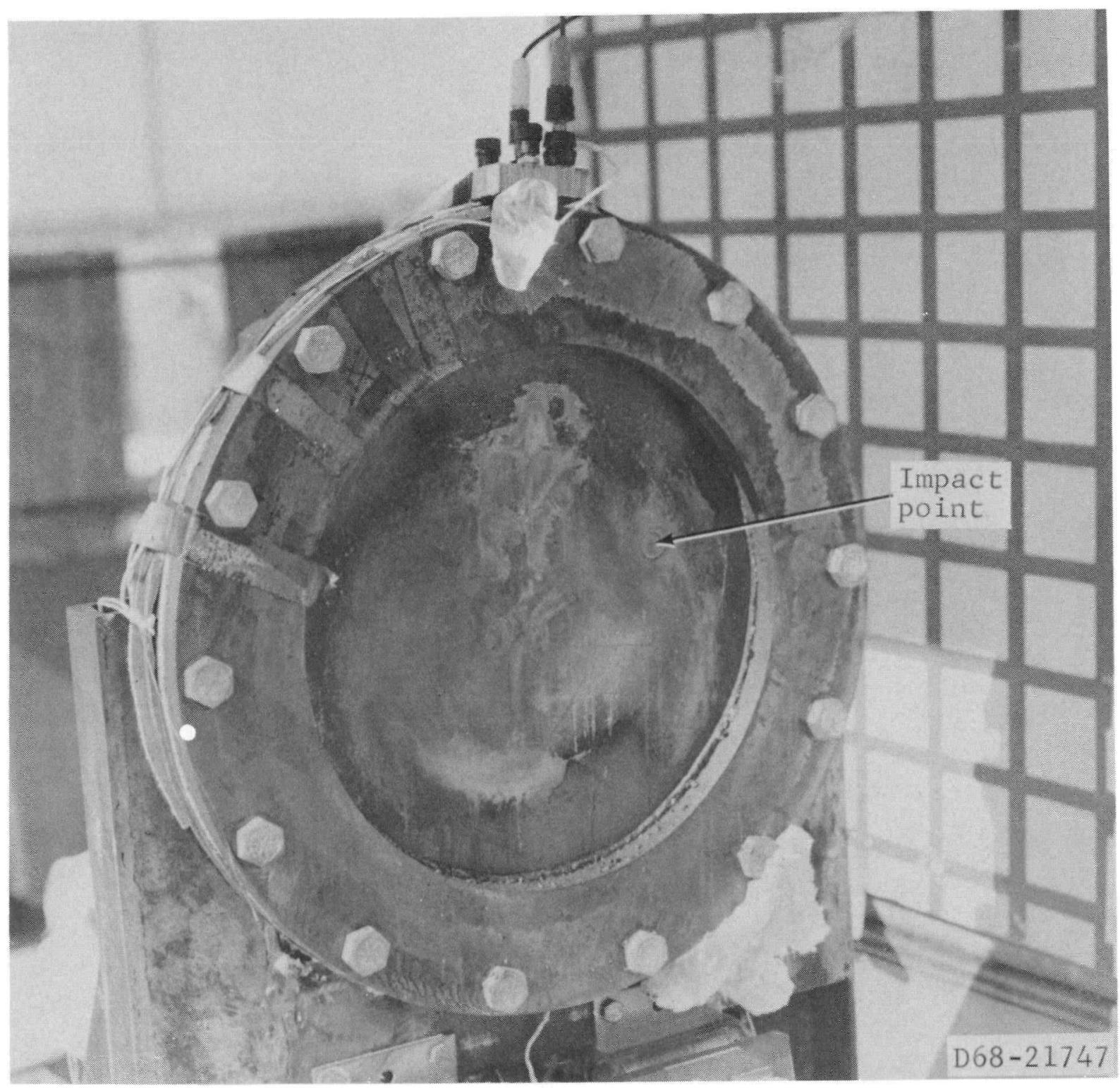

Figure 3. First beryllium plate (front) after 670 fps impact 


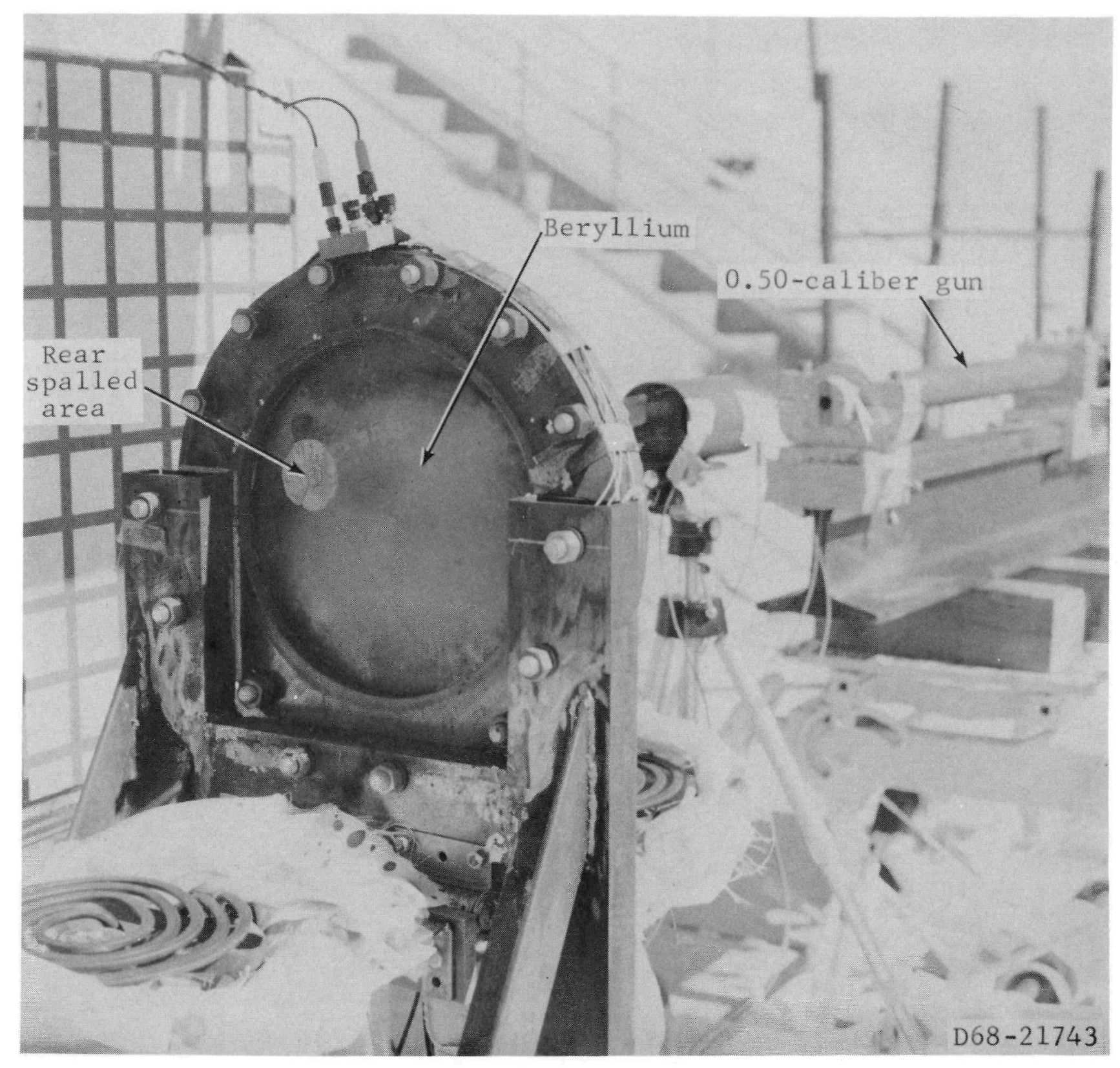

Figure 4. First beryllium plate (rear) after 670 fps impact 


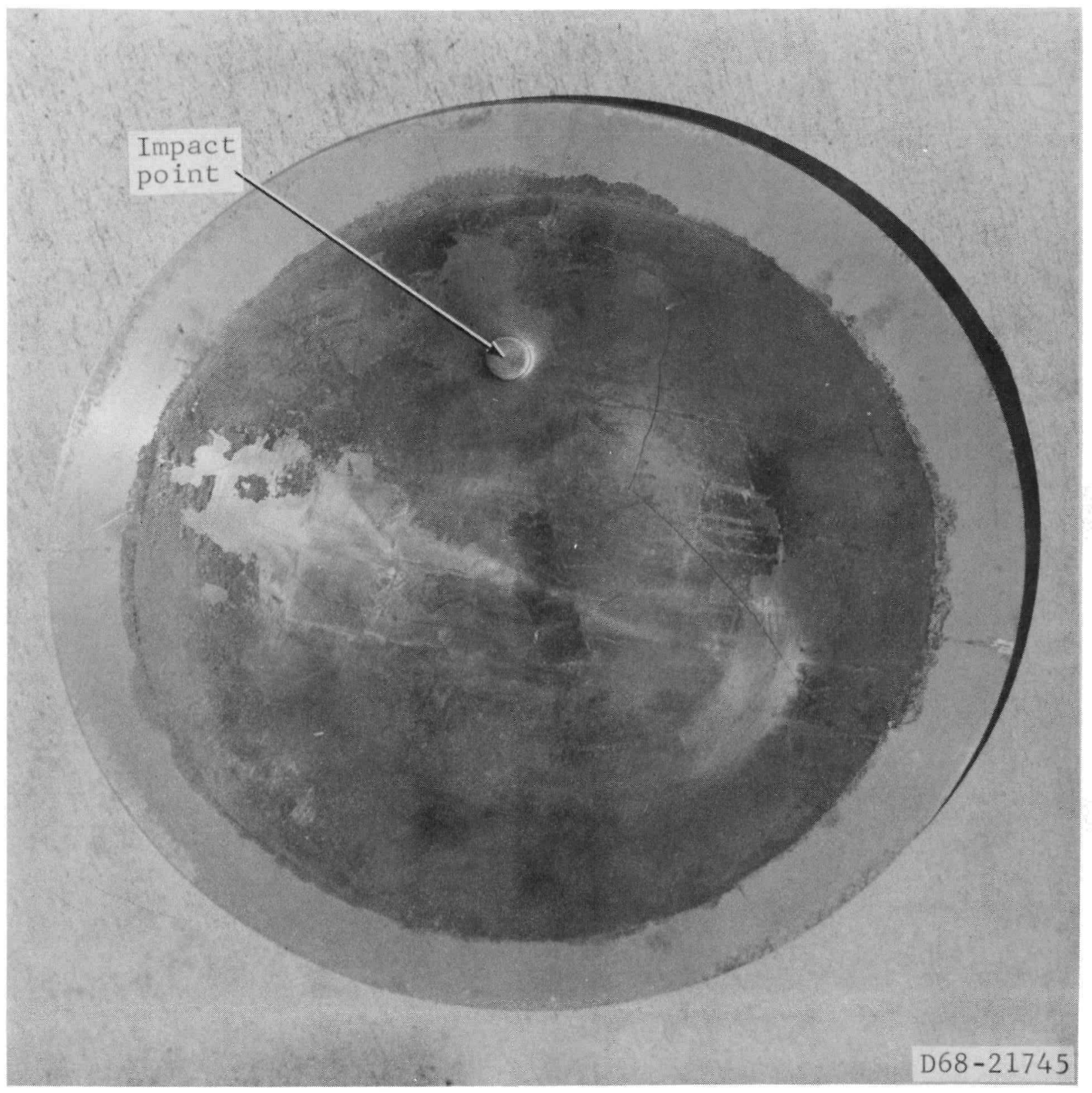

Figure 5. First beryllium plate (front) after 670 fps impact 


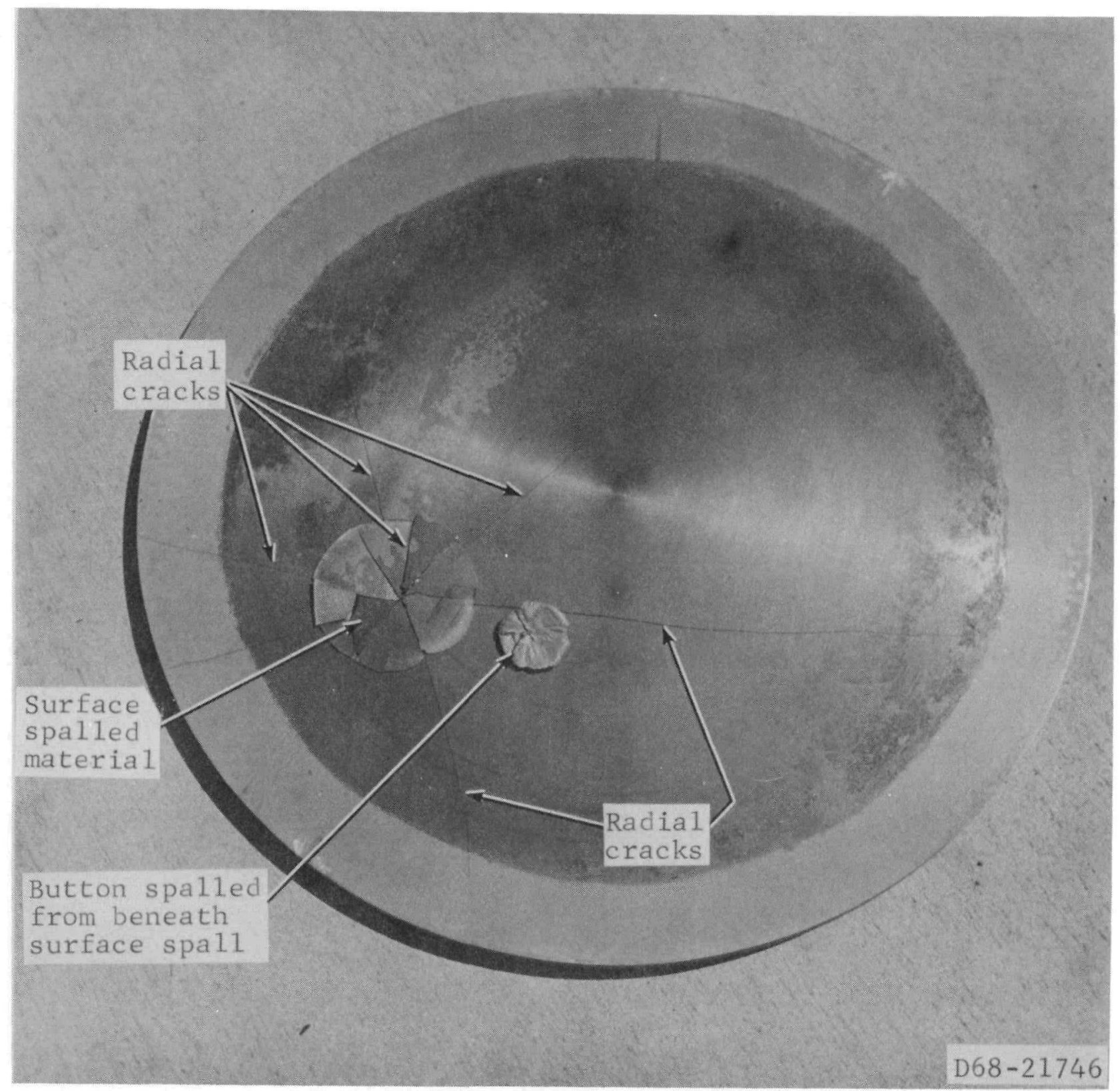

Figure 6. First beryllium plate (rear) after 670 fps impact 


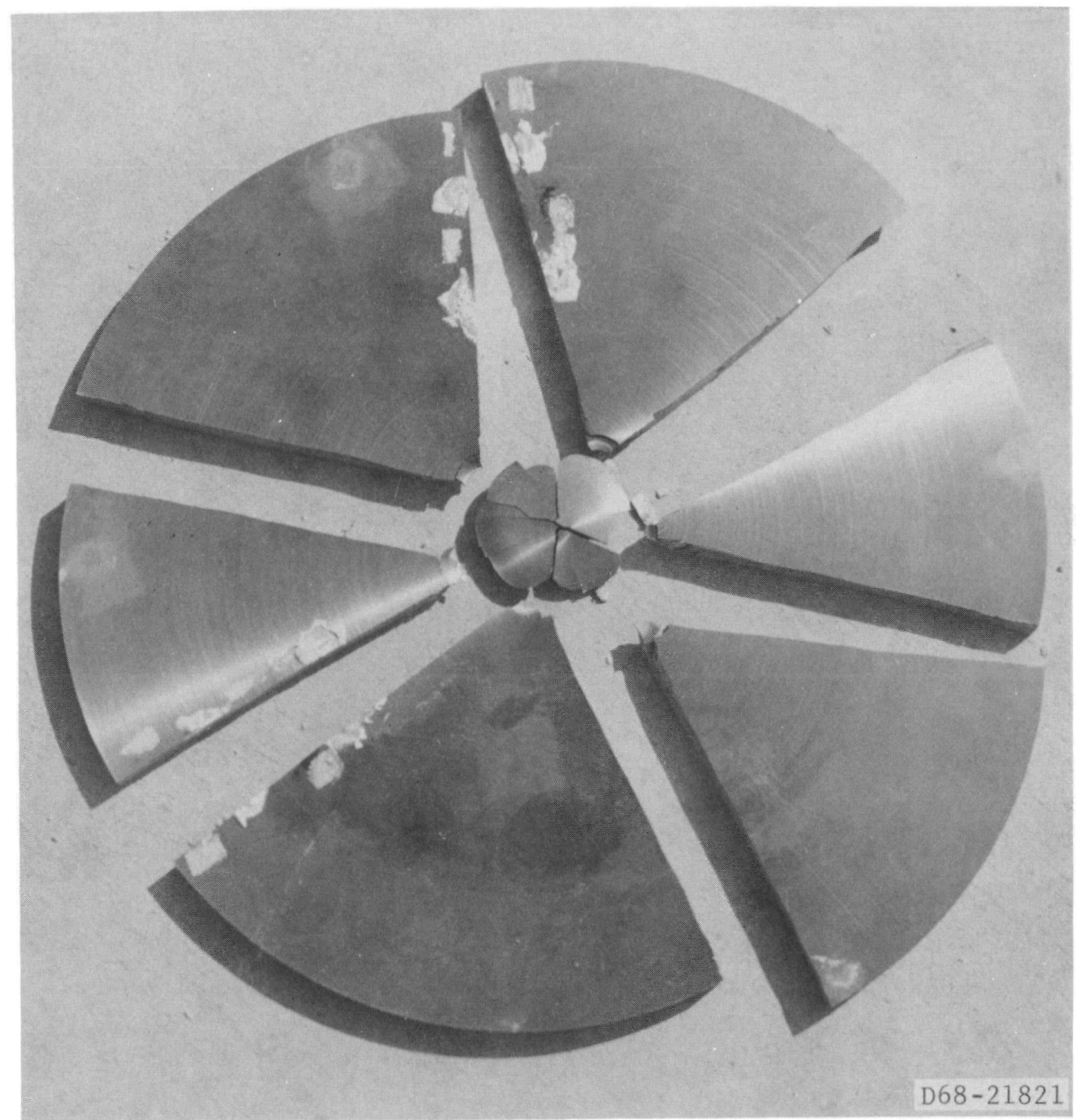

Figure 7. Second beryllium plate after 700 fps impact 


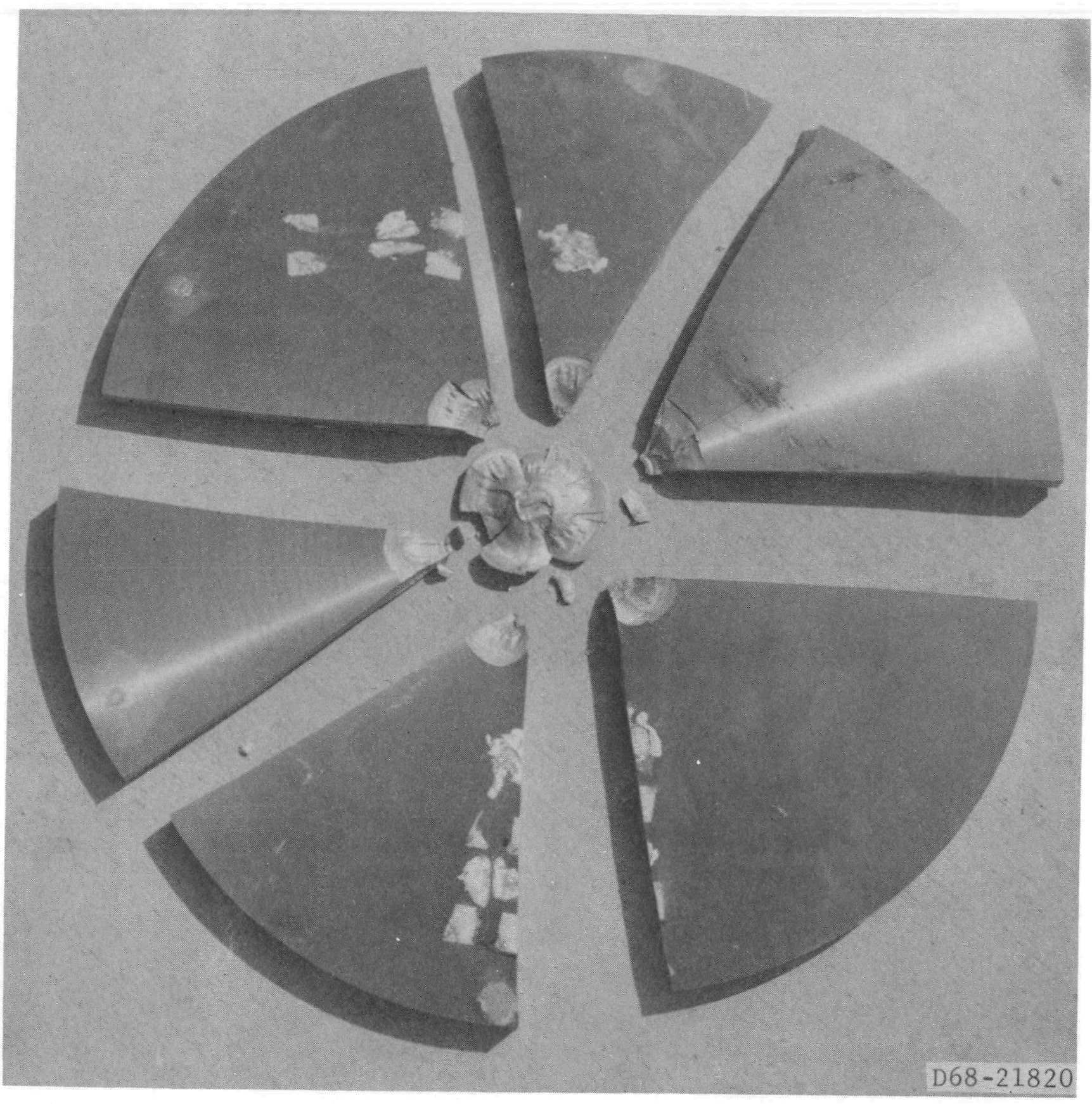

Figure 8. Second beryllium plate after $700 \mathrm{fps}$ impact 


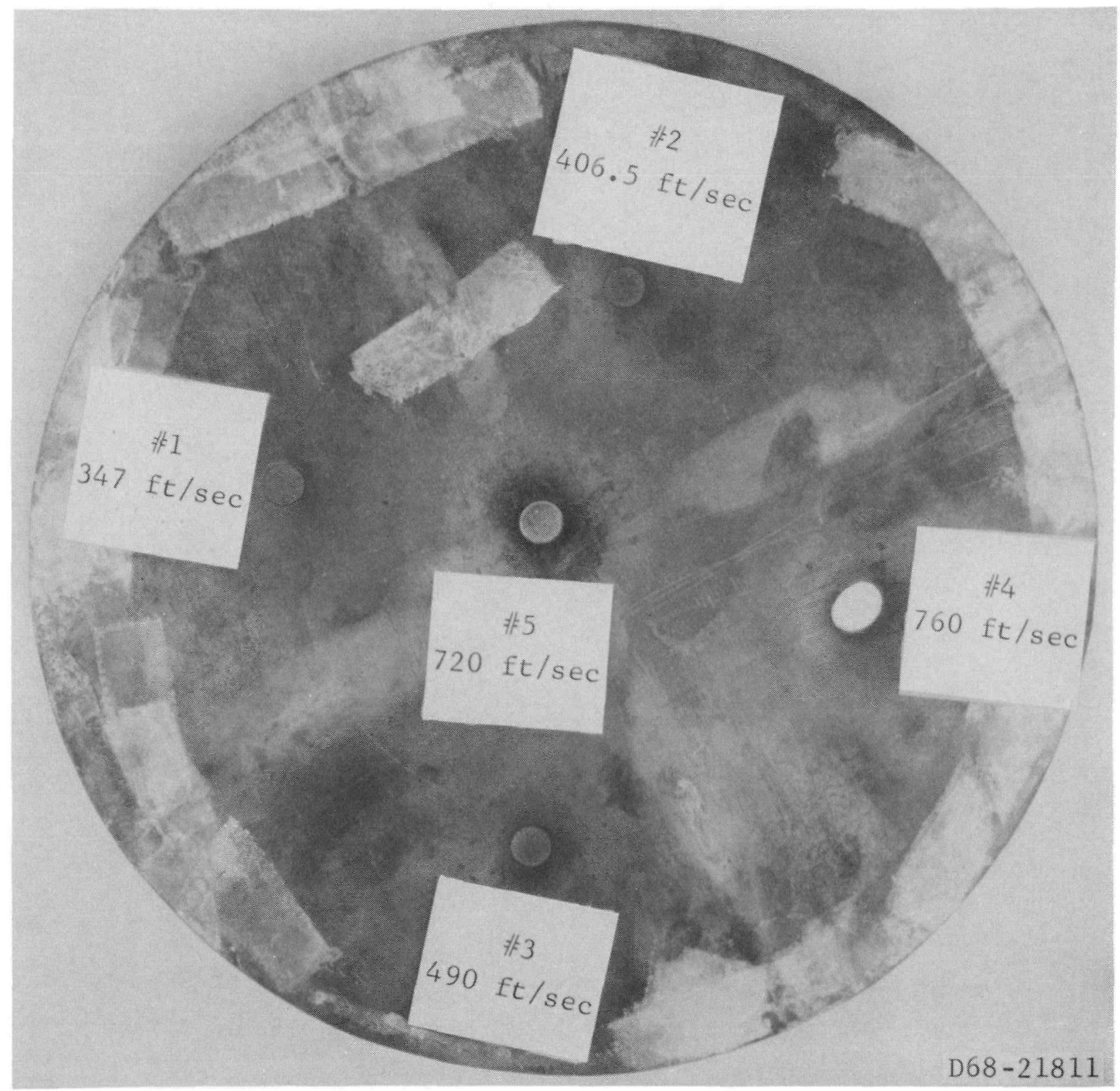

Figure 9. Haynes -25 alloy (front) 


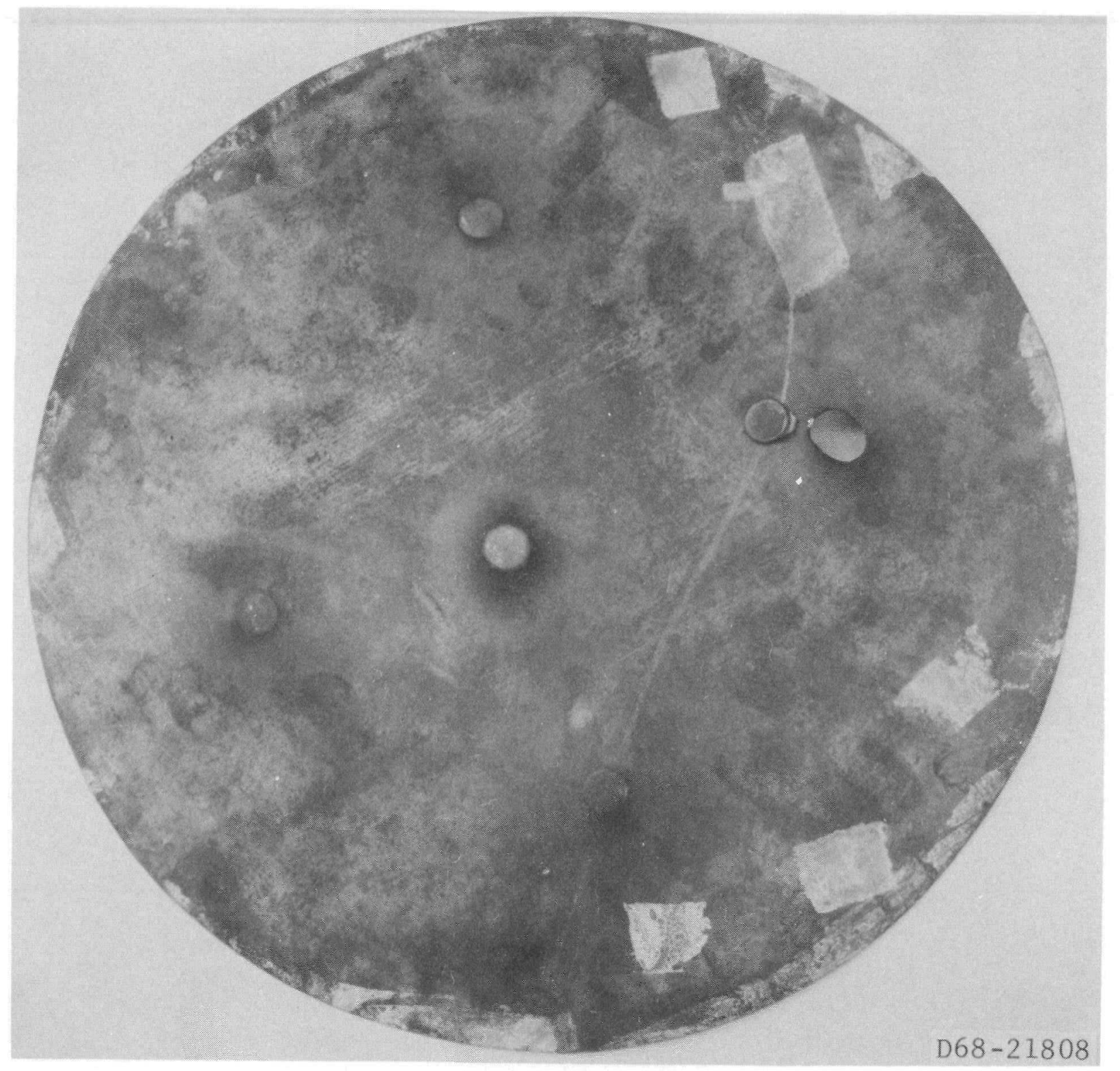

Figure 10. Haynes -25 alloy (rear) 


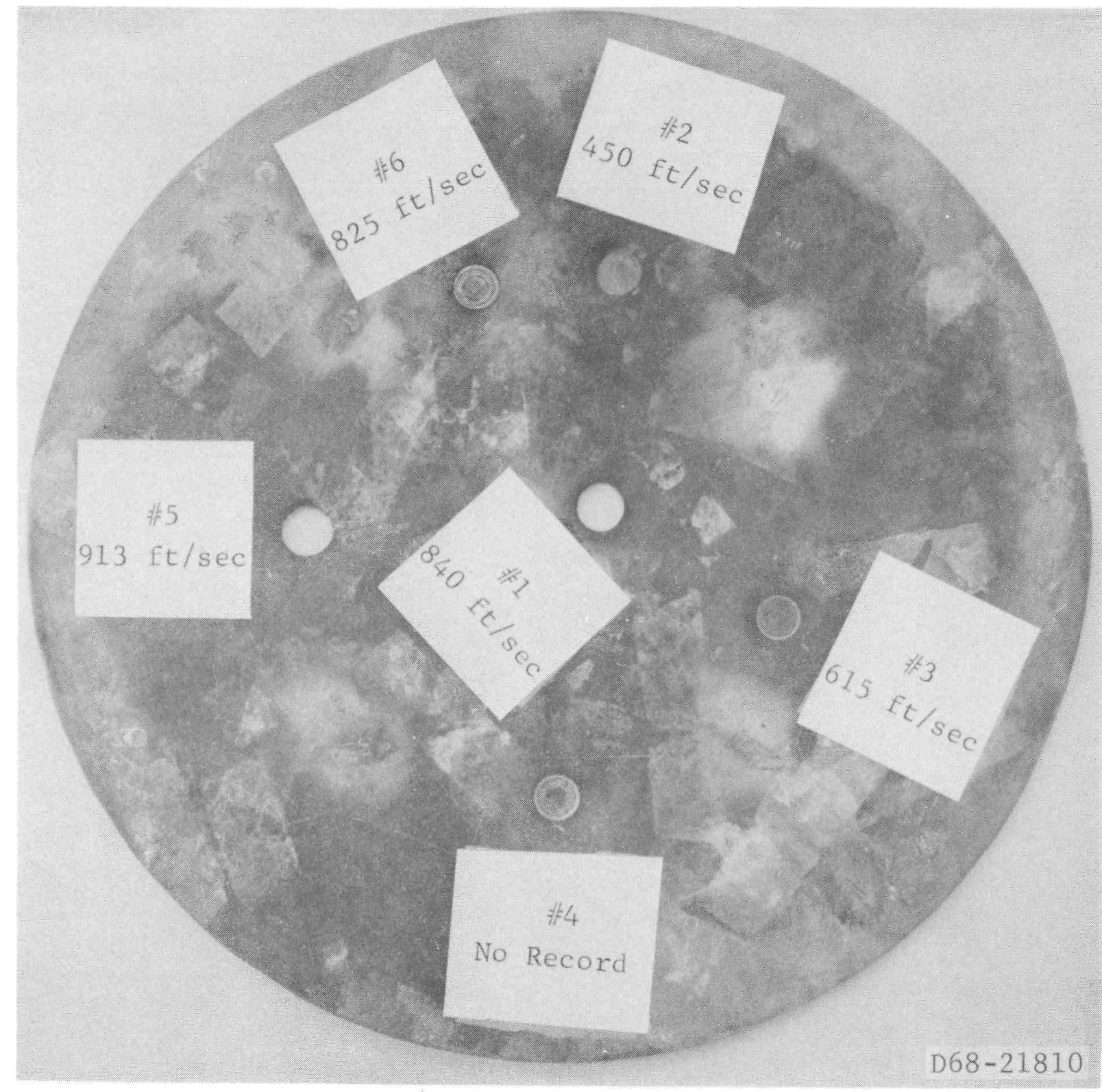

Figure 11. Titanium (6A1-4V) alloy (front) 


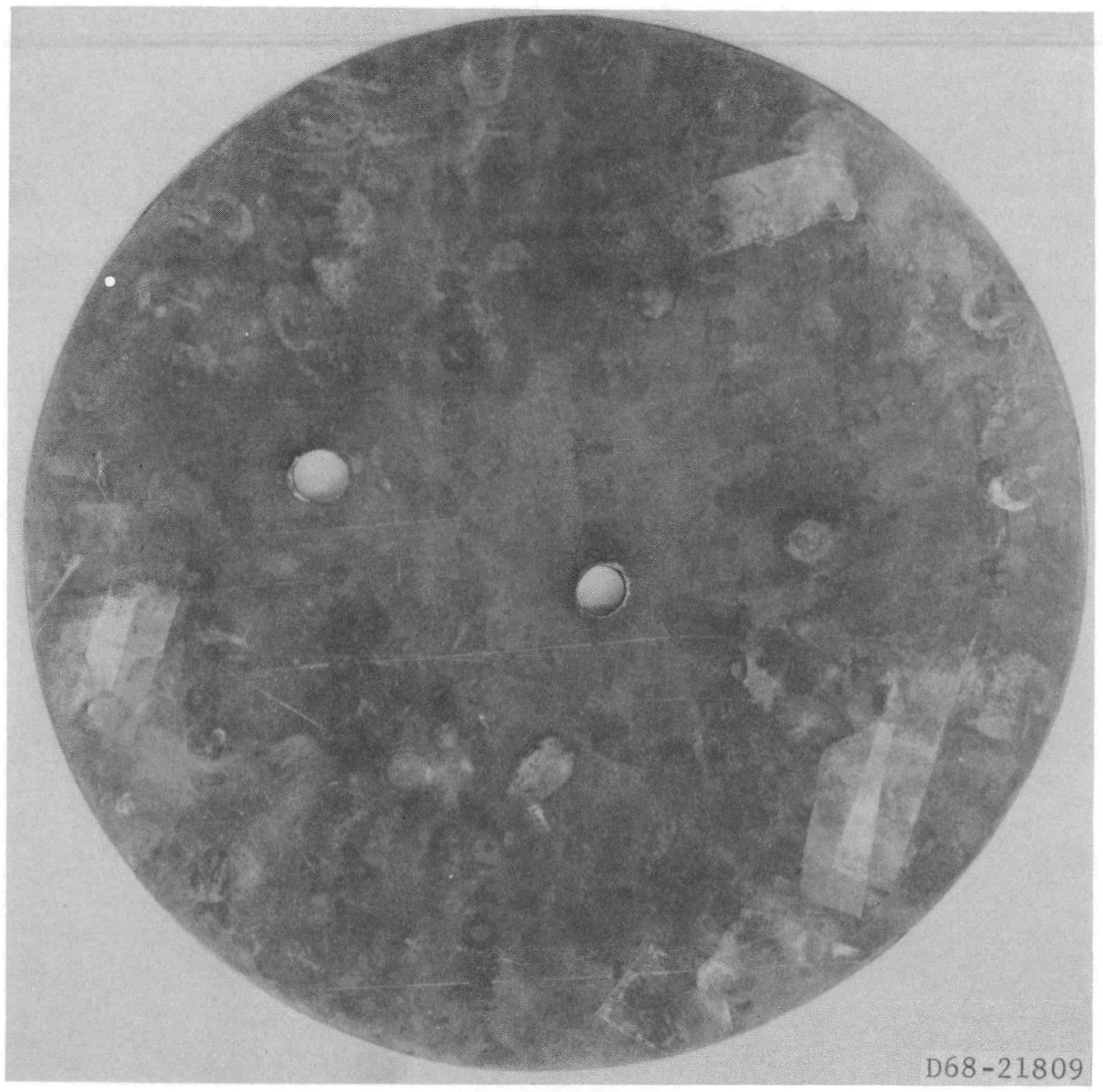

Figure 12. Titanium (6A1-4V) alloy (rear) 


\section{DISTRIBUTION :}

$$
\text { TID-4500 (54th Ed.) UC-36 }
$$

U. S. Atomic Energy Commission Division of Space Nuclear Systems Space Electric Power Office Washington, D.C. 20545

Attn: G. A. Newby Assistant Director (1)

G. P. Dix, Chief Safety Branch (1)

R. T. Carpenter, Chief Is otope Power Sys. Br.

J. A. Powers, Chief (1) Isotopes Fuels and Matl. Br. C. E. Johnson, Chief Reactor Power Sys. Br.

U. S. Atomic Energy Commission Space Nuclear Propulsion Office Washington, D.C. 20545

Attn: R. S. Decker, Jr. Chief, Safety Branch

U. S. Atomic Energy Commission Division of Isotope Development Washington, D.C. 20545

U. S. Atomic Energy Commission Director of Regulation Washington, D.C. 20545 Attn: C. K. Beck Deputy Director

R. W. Klecker (1) Div. of Reactor Licensing

U. S. Atomic Energy Commission Division of Biology and Medicine Washington, D.C. 20545

Attn: J. Z. Holland, Fallout Studies Br. (1)

H. D. Bruner, Asst. Dir. (1) Medical and Health Research

U. S. Atomic Energy Commission Space Nuclear Propulsion Office Albuquerque Extension Albuquerque Operations Office P. 0. Box 5400

Albuquerque, New Mexico 87115

Attn: H. P. Smith
U. S. Atomic Energy Commission Albuquerque Operations Office P. O. Box 5400

Albuquerque, New Mexico 87115

Attn: B. W. Colston Dir. Nonweapons Act. Div. For: J. Nicks (1)

J. F. Burke, Director Operationa1 Safety Div.

AEC Site Representative

National Aeronautics and Space Adm. Manned Space Center

Houston, Texas 77058

Attn: W. C. Remini Bldg. 16, Code ZS-5

Deputy I. G. for Insp. \& Safety USAF

Directorate of Nuclear Safety

Nuclear Power Division

Kirtland Air Force Base

New Mexico 87117

Jet Propulsion Laboratory

California Institute of Tech. 4800 Oak Grove Drive

Pasadena, California 91103

Attn: A. L. Klascius Radiation Health and Safety

Los Alamos Scientific Laboratory P. 0. Box 1663

Los Alamos, New Mexico 87544

Attn: Dr. L. D. P. King (1)

Dr. Wright Langham (1)

C. F. Metz, $\mathrm{CMB}-1$ (1)

F. W. Schonfeld, CMF-5 (1)

J. A. Leary, CMB-11 (1)

Monsanto Research Corporation

Mound Laboratory

P. 0. Box 32

Miamisburg, Ohio 45342

Attn: G. R. Grove

Thomas B. Kerr

Code RNS

National Aeronautics and Space Adm. Washington, D.C. 20545

Mr. Glenn Goodwin

National Aeronautics and Space Adm. Ames Research Center

$\mathrm{N}-200-4$

Moffett Field, California 
DISTRIBUTION (cont):

National Aeronautics and Space Adm. Goddard Space Flight Center

Glenn Dale Road

Greenbelt, Maryland 20771

Attn: A. W. Fihelly

Nimbus Project

Nava1 Facilities Engineering Com.

Dept. of the Navy, Code 042

Washington, D.C. 20390

Space Nuclear Propulsion Office

Lewis Research Center

21000 Brookpark Road

Cleveland, Ohio 44135

Attn: L. Nichols

Aerospace Safety Research and Data Ctr. National Aeronautics and Space Adm.

Lewis Research Center

21000 Brookpark Road

Cleveland, Ohio 44135

Attn: Paul Ordin

Union Carbide Corporation

Nuclear Division

P. 0. Box X

Oak Ridge, Tennessee 37831

Attn: R. A. Robinson

Isotope Dev. Center (1)

B. R. Fish

Health Physics Div.

U. S. Public Health Service

Nat. Ctr. for Radiological Health

1901 Chapman Avenue

Rockville, Maryland 20852

Attn: Nuclear Facilities Section

Dr. D. W. Sherwood

National Aeronautics and Space Adm.

Manned Space Center (MSC-TD)

Houston, Texas 77058
D. B. Shuster, 1200

J. H. Biffle, 1542 (2)

J. R. Holland, 5263

L. E. Lamkin, 7300

G. A. Fowler, 9000

J. R. Banister, 9150

R. C. Maydew, 9320

L. A. Hopkins, Jr., 9500

A. J. Clark, Jr., 9510

J. D. Shreve, 9511

S. L. Jeffers, 9512

R. E. Berry, 9512 (2)

S. McAlees, Jr., 9513

A. J. Clark, Jr., 9514 (Acting)

ARPIC, 9514 (2)

R. J. Everett, 9515

G. J. Hildebrandt, 9520

J. W. McKiernan, 9521

J. Jacobs, 9522

B. F. Hefley, 8232 (5)

J. L. Gardner, 3421

C. H. Sproul, 3428-2

G. C. McDonald, 3416

Attn: M. S. Goldstein, 3416

L. C. Baldwin, 3412

L. L. Alpaugh, 3412 